\title{
Epigrammatic study on the effect of lockdown amid Covid-19 pandemic on air quality of most polluted cities of Rajasthan (India)
}

\author{
Madhuben Sharma ${ }^{1} \cdot$ Sapna Jain $^{2}$ (D) $\cdot$ Bhawna Yadav Lamba ${ }^{2}$ \\ Received: 25 May 2020 / Accepted: 9 July 2020 / Published online: 15 July 2020 \\ (C) Springer Nature B.V. 2020
}

\begin{abstract}
Covid-19 pandemic has adversely affected all the aspects of life in adverse manner; however, a significant improvement has been observed in the air quality, due to restricted human activities amidst lockdown. Present study reports a comparison of air quality between the lockdown duration and before the lockdown duration in seven selected cities (Ajmer, Alwar, Bhiwadi, Jaipur, Jodhpur, Kota, and Udaipur) of Rajasthan (India). The period of analysis is 10 March 2020 to 20 March 2020 (before lockdown period) versus 25 March to 17 May 2020 (during lockdown period divided into three phases). In order to understand the variations in the level of pollutant accumulation amid the lockdown period, a trend analysis is performed for $24 \mathrm{~h}$ daily average data for five pollutants $\left(\mathrm{PM}_{2.5}, \mathrm{PM}_{10}, \mathrm{NO}_{2}, \mathrm{SO}_{2}\right.$, and ozone).
\end{abstract}

Keywords Covid-19 $\cdot$ Air quality $\cdot \mathrm{NO}_{2} \cdot$ Air pollutant $\cdot$ Particulate matter $\cdot$ Ozone

\section{Introduction}

At the end of the year 2019, China's health authority ominously reported to the World Health Organization (WHO) about a severe type of pneumonia in Wuhan city of Hubei Province in central China (Lu et al. 2020). The report addressed the severe acute respiratory syndrome corona virus (SARS-CoV-2), now popularly known as Covid-19. It was declared as a pandemic on March 11, 2020, by WHO (Gorbalenya et al. 2020); it has caused over 4.8 million global infections and more than 3.2 lakhs confirmed deaths in 216 countries, as of this writing (21 May 2020) (WHO 2020). In India, over one lakh cases have been confirmed with a death record of over 3700, until 21 May 2020 (GOI (Government of India) 2020).

Considering the population in India, the conditions are still not as frightening as in other countries of the world. This can be attributed to the early preventive measures taken by the government of India. In order to combat the pandemic and

Sapna Jain

sapnaj22@gmail.com

1 School of Engineering, University of Petroleum and Energy Studies, Bidholi, Energy Acres, Dehradun, Uttarakhand 248007, India

2 Department of Applied Sciences and Humanities, School of Engineering, University of Petroleum and Energy Studies, Bidholi, Energy Acres, Dehradun, Uttarakhand 248007, India restrict the further spread of the virus from one source to another, multiple interventions, including lock down, have been implemented. The schedule of the Covid-19 pandemic lockdown in India is given in Table 1.

The lockdown includes ban on travel on all modes of transports (surface, air, and water) and closures of factories, causing cessation of business including tourism, various industries, local markets, construction, food business, and mining. However, there was a time liberty for essential services like medicines, groceries, fruits, and vegetables. The immediate lateral consequence is observed as dip in the economy, globally and nationwide, that may take years to return at par with the previous conditions. The lockdown has benefited the environment in terms of improvement in air quality and water quality, and decline in noise pollution level (Mandal and Pal 2020; Masum and Pal 2020; Bherwani et al. 2020). Worldwide, many researchers have reported a waning in the air pollution due to restricted social and economical activities amidst lockdown (Bao and Zhang 2020; Jain and Sharma 2020).

As per data of World Air Quality Report (2018-2019) and other sources (2020), more than 20 Indian cities are in the 30 most polluted cities in the world (WAQR, World air quality report 2019; WAQR, World air quality report 2018; CNN Health 25th 2020). In the year 2018, four cities of Rajasthan were in top 100 most polluted cities in world with Bhiwadi city at the fifth position (WAQR, World air quality report 2018). According to a report (2018), Rajasthan has the highest 
Table 1 Schedule of Covid-19 pandemic lockdown in India

\begin{tabular}{llll}
\hline Phase & Start of the lockdown & End of the lockdown & Total days \\
\hline Phase -1 & 25 March 2020 & 14 April 2020 & 21 \\
Phase -2 & 15 April 2020 & 3 May 2020 & 19 \\
Phase -3 & 4 May 2020 & 17 May 2020 & 14 \\
Phase -4 & 18 May 2020 & Ongoing (scheduled to end on 31 May) & - \\
\hline
\end{tabular}

death rate per lakh due to air pollution, i.e., because of exposures to ambient air pollutants over a prolonged period of time (TOI (Times of India) 2018).

Considering the previous severe pollution situation in Rajasthan, we have studied the current air quality in seven cities of Rajasthan: Ajmer, Alwar, Bhiwadi, Jaipur, Jodhpur, Kota, and Udaipur.

\section{Types of air pollutants and their sources (Aranha 1994)}

On the basis of origin, air pollutants can be categorized as primary or secondary. Primary air pollutants are directly emitted into the air from their source. For example, oxides of sulfur, oxides of nitrogen, and oxides of carbon are primary air pollutants.

Sulfur dioxide $\left(\mathrm{SO}_{2}\right)$ is formed due to burning of nonconventional fuels, agriculture wastes or residues, or from industries. It is considered to be toxic after a certain concentration. It is also responsible for acid rain formation. Nitrogen oxides $\left(\mathrm{NO}_{\mathrm{x}}\right)$, like nitrogen dioxide $\left(\mathrm{NO}_{2}\right)$, are formed during combustion of fossil fuels, biomass, etc. It may also react with carbon monoxide in the atmosphere to form ozone. It is also responsible for acid rain. Carbon monoxide (CO) is formed due to incomplete combustion of carbon in fuels like motor and industry biomass.

Secondary air pollutants are formed due to the reaction of primary air pollutants in the atmosphere. For example, ozone $\left(\mathrm{O}_{3}\right)$ is formed by free radical reactions of nitrogen oxides. Smog is formed from smoke and fog. The particulate matter (PM) (aerosols) are the solid and liquid particles suspended in the air, viz., organic compounds, metals, acids, soil, and dust. Thus, they include both organic and inorganic matter. These coarse particles are formed by mechanical break up of large solid particles obtained from non-combustible materials produced during combustion of fossil fuels, agricultural processes, mining of ores, construction of roads, etc.

The different kind of air pollutants and their sources are summarized in Table 2.

\section{Area of study}

Rajasthan, the largest state of the India, is located at the northwestern part of the country. The state lies between N-latitude $23^{\circ} 31^{\prime}$ to $30^{\circ} 12^{\prime}$ and E-longitude $69^{\circ} 3^{\prime}$ to $78^{\circ}$ (Fig. 1) with an area of about $3.4 \mathrm{~km}^{2}$ (Maps of India 2011). Geomorphologically, the state can be divided into four units, viz., Eastern plain areas, Aravali hill ranges and adjacent areas, Western sandy plains and sand dunes, and low lying Vindhayan hill. The State suffers from impulses of monsoon, showing rainfall as low as $170 \mathrm{~mm}$ in the western part of the state and as high as $819 \mathrm{~mm}$ in the eastern part of the state (Maanju and Saha 2013).

At the time of establishment of Rajasthan, the economy of the State was predominantly an agrarian economy. The state has an agricultural economy with nine agro-climatic zones and various types of soil that help during the cultivation of crops. With the advent of industrialization, it started playing an important role in providing substantial employment and generating the income and boosting the standard of living and overall welfare of people. Majorly, industries started flourishing in Kota, Jaipur, Udaipur, Bhilwara, Bhiwadi, and few other Industrial Estates of Rajasthan. The key industries of Rajasthan are cement, tourism, ceramic, chemicals, textiles, steel, handicrafts, IT and ITeS, and marble (Maps of India 2011; Report 2018). Researchers have reported that in Rajasthan, the industrial activities, mining, and automobiles are responsible for air pollution (Kumar and Sharma 2016; Chauhan 2010). In India, Rajasthan is one of the largest mineral-producing states, with availability of more than 80 kinds of minerals out of which 57 minerals are produced commercially. The tourist attractions of Rajasthan (historic monuments, wildlife sanctuaries, deserts, etc.) offer an attractive investment opportunity to developers and investors. Also, the state is the leading producer of cement grade limestone in India. The state has about $26 \%$ share in proven limestone reserves in the country (IBEF : India Brand Equity Foundation 2020).

Air pollution caused by industries has been responsible for serious occupational health hazards and adverse effects. The Rajasthan Pollution Control Board (RSPCB) has been regularly tracking the impact of the industrial activities on air quality in Jaipur, Alwar, Ajmer, Bhiwadi, Jodhpur, Kota, Pali, and Udaipur.

Jaipur city, as one of the fastest growing cities of India, faces expanding urbanization, with traffic congestion, poor road conditions, poor control of industrial emission, and increase in air pollution (Dhamaniya 2004; Kala et al. 2014). 
Table 2 Sources of air pollutants

\begin{tabular}{|c|c|c|c|}
\hline $\begin{array}{l}\text { Name of the } \\
\text { pollutant }\end{array}$ & Sources of pollutant & $\begin{array}{l}\text { Study } \\
\text { area }\end{array}$ & Reference \\
\hline $\mathrm{PM}_{2.5}$ & $\begin{array}{l}\text { Burning of farm residue/open biomass } \\
\text { burning, bio- and fossil-fuel } \\
\text { combustion, household cooking, road } \\
\text { dust, emission from vehicle exhaust, } \\
\text { and industrial processes }\end{array}$ & India & $\begin{array}{l}\text { Singh 2018; Guttikunda et al. 2016; } \\
\text { Sharma and Dikshit 2016; Lelieveld } \\
\text { et al. 2015; Chafe et al. 2014; Yadav } \\
\text { et al. } 2014\end{array}$ \\
\hline $\mathrm{PM}_{10}$ & $\begin{array}{l}\text { Burning of farm residue/biomass burning, } \\
\text { cement industries, bio- and fossil-fuel } \\
\text { combustion, industrial processes, wind- } \\
\text { blown dust, building construction, lime } \\
\text { kilns, slab polishing, marble stone } \\
\text { devastating, vehicle travel on paved and } \\
\text { unpaved roads, dust from open fields } \\
\text { and farmlands. }\end{array}$ & India & $\begin{array}{l}\text { Singh 2018; Sheikh and Najar 2018; } \\
\text { Yadav et al. } 2014\end{array}$ \\
\hline $\mathrm{SO}_{2}$ & $\begin{array}{l}\text { Diesel driven personal vehicles, freight } \\
\text { vehicles exhaust (vehicular traffic), } \\
\text { diesel generator sets, burning of fossil } \\
\text { fuels in industries } \\
\text { Industrial activities occurring in } \\
\text {-iron and steel smelting unit } \\
\text { •production of basic metals, metal } \\
\text { products, and machinery } \\
\text { •fertilizer unit } \\
\text { •cement unit }\end{array}$ & India & $\begin{array}{l}\text { Guttikunda et al. 2019; Sheikh } \\
\text { and Najar 2018; Pant and } \\
\text { Chandramauli 2018; } \\
\text { Gurjar et al. } 2016\end{array}$ \\
\hline $\mathrm{NO}_{2}$ & $\begin{array}{l}\text { Industries, burning of fossil fuels, } \\
\text { construction activities, and vehicular } \\
\text { emission }\end{array}$ & India & $\begin{array}{l}\text { Guttikunda et al. 2019; Pant and } \\
\text { Chandramauli 2018; Sheikh } \\
\text { and Najar 2018; Sahu et al. } 2012\end{array}$ \\
\hline
\end{tabular}

The high concentration of air pollutants has worsened the human health (Tandon et al. 2008) and quality of life. The increased level of air pollutants in urban area is responsible for deficits in pulmonary functions, cardiovascular disease, neuro-behavioral effects, and mortality (WHO 2005a, b).

\section{Methodology}

The impact of lockdown on air quality of seven selected cities of Rajasthan (Ajmer, Alwar, Bhiwadi, Jaipur, Jodhpur, Kota, and Udaipur) (Fig. 1) has been reviewed for two time periods.
Fig. 1 Study area with location of selected cities: Ajmer, Alwar, Bhiwadi, Jaipur, Jodhpur, Kota, and Udaipur

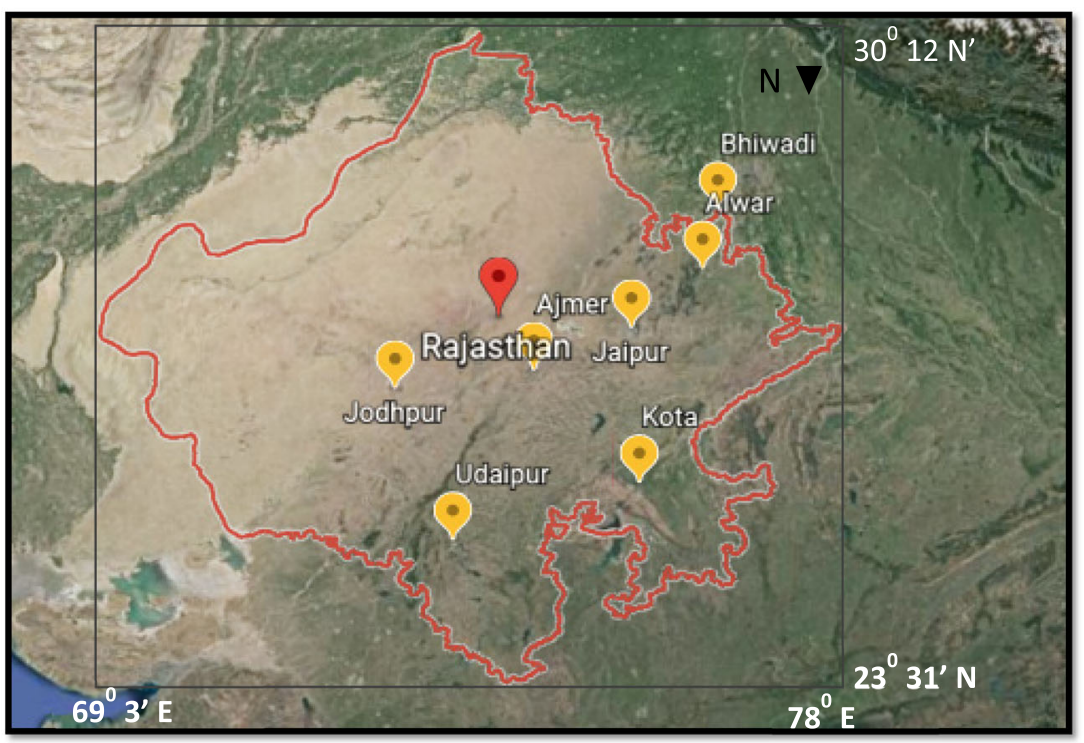


(a) Before lockdown period: 10 March 2020 to 20 March 2020

(b) During lockdown period: 25 March to 17 May 2020

The continuous ambient quality data for the selected cities have been acquired through the Central Pollution Control Board, New Delhi (CPCB). The data included five criteria air pollutants: (i) particular matter of size less than $2.5 \mu \mathrm{m}$ $\left(\mathrm{PM}_{2.5}\right)$, (ii) particular matter of size less than $10 \mu \mathrm{m}$ $\left(\mathrm{PM}_{10}\right)$, (iii) sulfur dioxide $\left(\mathrm{SO}_{2}\right)$, (iv) nitrogen dioxide $\left(\mathrm{NO}_{2}\right)$, and (v) ozone $\left(\mathrm{O}_{3}\right)(\mathrm{CPCB} 2020)$.

\section{Results and discussion}

The results are depicted in the Fig. 2 and Fig. 3.

The temporal analysis of the variation in the levels of criteria air pollutants revealed that there was a significant decline in the concentration of all pollutants except for ozone $\left(\mathrm{O}_{3}\right)$ in all the cities of Rajasthan under examination (Figs. 2 and 3); however, the concentration of ozone observed a decline in Jaipur city (Fig. 3a). The decrease in the concentration of the air pollutants was more significant in the first phase of the lockdown as compared with the next two phases of lockdown. This can be attributed to the relaxation provided in the later phases of lockdown.

As depicted in Figs. 2 and 3, there is no violation of the National Ambient Air Quality Standards (NAAQS for $\mathrm{PM}_{2.5}=60 \mu \mathrm{g} \mathrm{m}^{-3}, \mathrm{PM}_{10}=100 \mu \mathrm{g} \mathrm{m}^{-3}, \mathrm{SO}_{2}=80 \mu \mathrm{g} \mathrm{m}^{-3}$, $\mathrm{NO} 2=80 \mu \mathrm{g} \mathrm{m}^{-3}$ based on 24-hour average, and $\mathrm{O}_{3}=$ $100 \mu \mathrm{g} \mathrm{m}^{-3}$ based on 8 -h average) during the lockdown period in the seven cities of Rajasthan.
Furthermore, all criteria pollutants are within the NAAQS limit before lockdown except for $\mathrm{PM}_{10}$ in Jaipur, Jodhpur, Bhiwadi, and Ajmer with average concentrations being

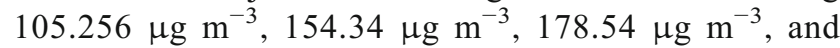
$110.30 \mu \mathrm{g} \mathrm{m}^{-3}$ as presented in Figs. 2 and 3.

Table 3 represents the percentage change in all the criteria pollutants considered in the selected cities of Rajasthan for a period of assessment, i.e., before lockdown versus during lockdown (average of all the three phases of lockdown) amid Covid-19. The result of the analysis showed that the most significant dip was observed in the $\mathrm{NO}_{2}$ concentration, in all the seven cities of the Rajasthan with maximum decline of $64 \%$ being observed in Bhiwadi city of Rajasthan, before and during lockdown duration in 2020. A similar decline in nitrogen dioxide concentration was also reported in China due to Covid-19 pandemic (Dutheil et al. 2020). The concentration of $\mathrm{SO}_{2}$ showed a noticeable change in Bhiwadi, Alwar, and Jodhpur. In Bhiwadi, maximum decline in concentrations of $\mathrm{PM}_{10}, \mathrm{PM}_{2.5}$, and $\mathrm{SO}_{2}$ was observed, $\sim 58.2 \%$ (178.54 to $\left.98.74 \mu \mathrm{g} \mathrm{m}^{-3}\right), \sim 44.69 \%$ (95.98 to $40.09 \mu \mathrm{g} \mathrm{m}^{-3}$ ), and $69.90 \%$ (41.01 to $12.34 \mathrm{mg} \mathrm{m}^{-3}$ ) respectively, during lockdown phase in comparison with that before the lockdown period.

Reports of other cities in India and China showed a similar pattern of decrease in concentration of the air pollutants except ozone. The concentration of ozone was found to be increased during the lockdown period in other parts of world (Xu et al. 2020; Jain and Sharma 2020). In the current study, the maximum percentage of increase (45\%) in $\mathrm{O}_{3}$ was witnessed in Kota. In order to understand the unlikely trend in the change in concentration of ozone, let us see the photochemical reactions responsible for formation of ozone in the atmosphere (Fig. 3c).
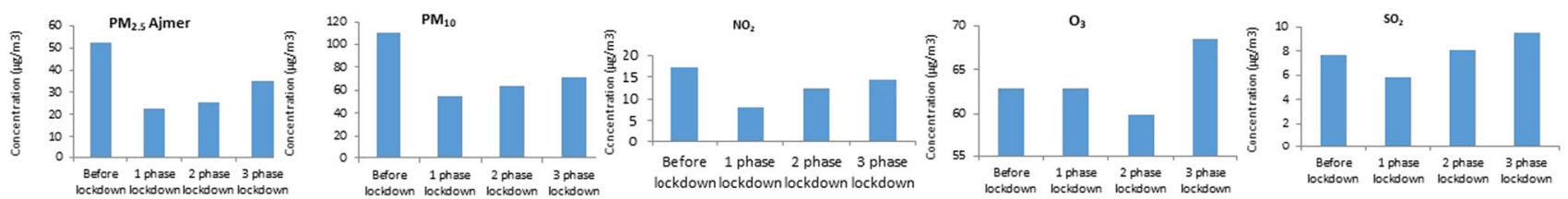

a Ajmer
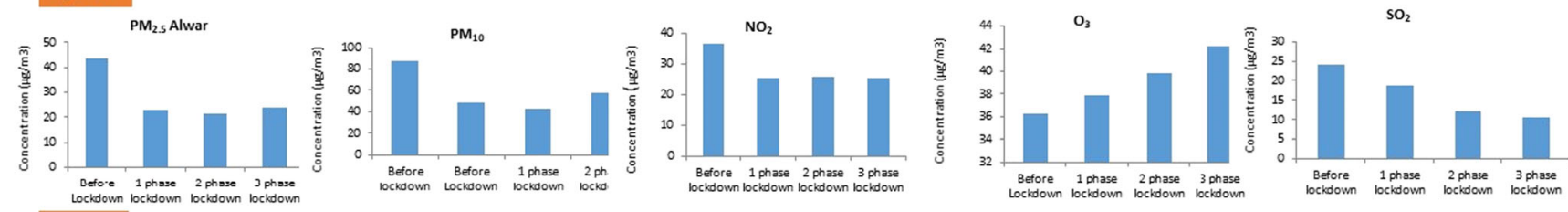

b Alwar
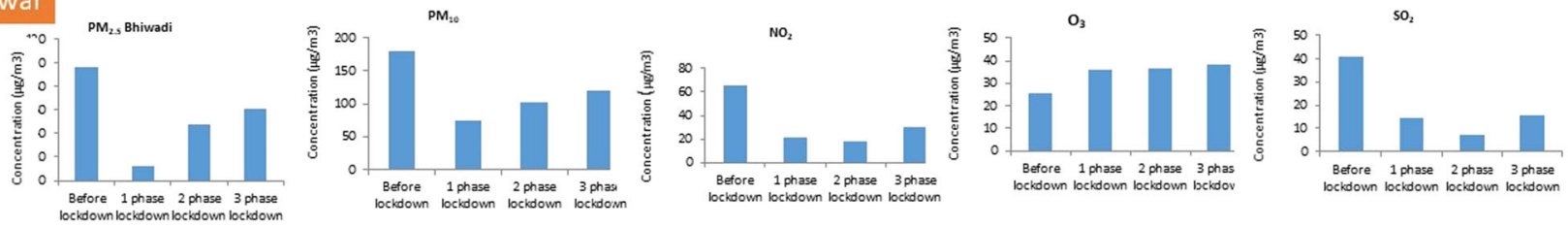

Bhiwadi

Fig. 2 Air pollutants in different cities before lockdown and after lockdown of three phases. (a) Ajmer, (b) Alwar, (c) Bhiwadi 

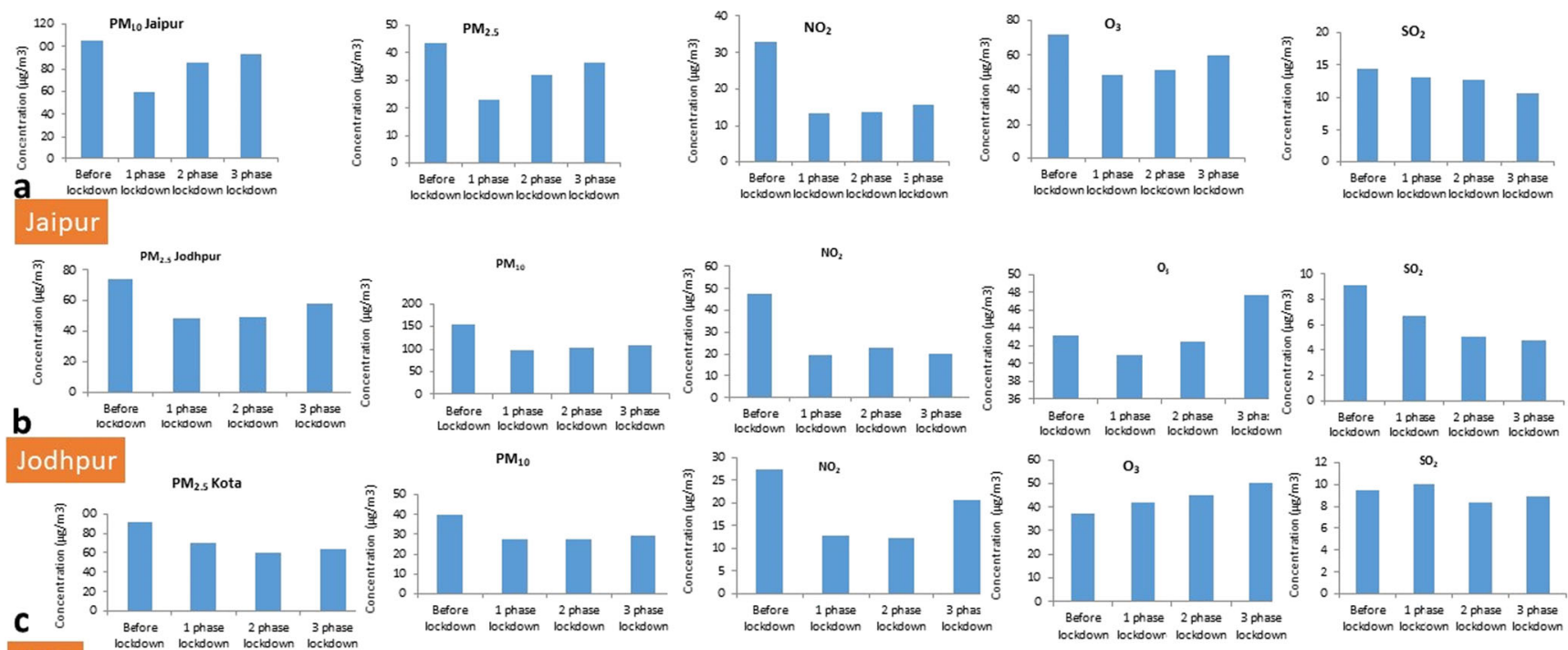

$\mathrm{PM}_{10}$
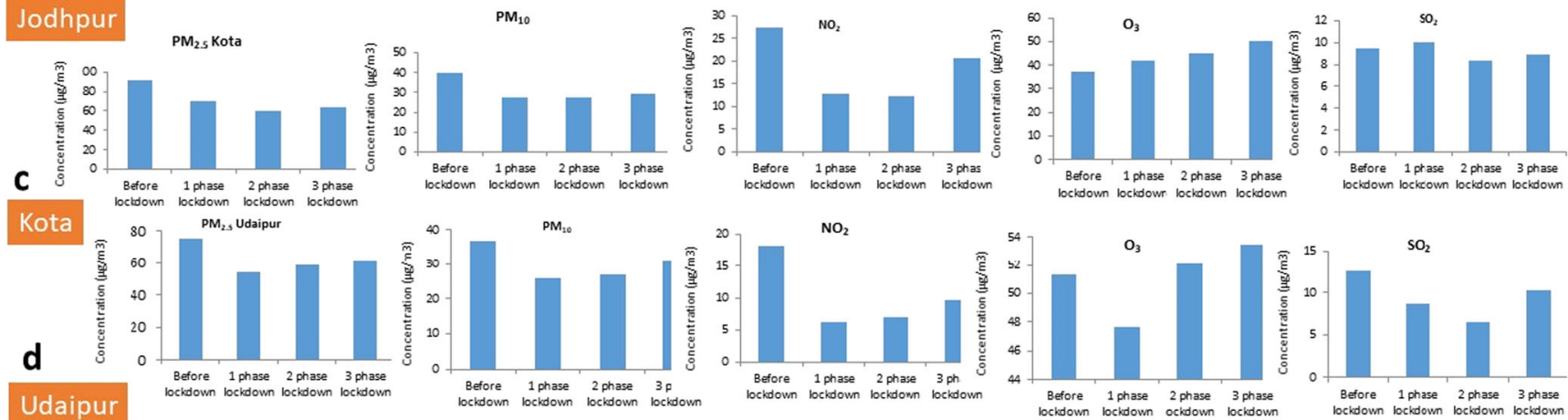

Fig. 3 Air pollutants in different cities before lockdown and after lockdown of three phases. (a)Jaipur (b) Jodhpur (c) Kota, and (d) Udaipur

Nitrogen oxides (NOx) and volatile organic compounds (VOCs) are referred as ozone precursors. The ambient concentration of ozone is governed by the mentioned precursors, temperature, solar radiations, wind speed, and other meteorological factors. As reported, ozone is produced by a complex reaction taking place among NOx and VOCs in the presence of sunlight (Srivastava et al. 2005; Lee et al. 2002). The present study area is urban part and thus falls under VOC-limited region of the country (Seinfeld and Pandis 1998). In a VOClimited environment, the ozone accumulation is directed by the chemistry between the anthropogenic emission of $\mathrm{NOx}$ and ozone, beside the meteorological factors (Saini et al. 2017). Thus, the increase in concentration of ozone during lockdown period could be correlated to increased solar radiation and decrease $\mathrm{NO}_{2}$ owing to favorability of the photochemical reaction (Fig. 4). More than $75 \%$ of nitrogen is released from activities like agriculture, transport (fossil-fuel combustion), and industries [17], and during lockdown, there was a restriction in all the mentioned sectors, leading to lowering of the concentration of NOx emissions in VOC-limited environment, which could be correlated to the increase in concentration of ozone in most of the selected cities (Kim et al. 2018; Sicard et al. 2020; Shrestha et al. 2020; Sharma et al. 2016).

It is also documented that decrease in the concentration of PM causes more infiltration of solar radiation through the atmosphere. The presence of more solar energy enhances the photochemical activities, thereby increases $\mathrm{O}_{3}$ production in the atmosphere (Dang and Liao 2019; Li et al. 2019).

Furthermore, the reduction in $\mathrm{PM}_{2.5}$ levels during the lockdown period may also be credited to reduce $\mathrm{NO}_{2}$ levels, an important factor in the formation of secondary PM (Jain and Sharma 2020). In addition to transportation, the other factors that resulted in a reduction in air pollution levels are shutdown
Table 3 Percentage of change in the criteria pollutants of selected cities in Rajasthan, before and during lockdown amid Covid-19 (average of the three phases of lockdown)

\begin{tabular}{llllll}
\hline Cities & $\begin{array}{l}\text { Percentage } \\
\text { change in } \mathrm{PM}_{2.5}\end{array}$ & $\begin{array}{l}\text { Percentage } \\
\text { change in } \mathrm{PM}_{10}\end{array}$ & $\begin{array}{l}\text { Percentage } \\
\text { change in } \mathrm{NO}_{2}\end{array}$ & $\begin{array}{l}\text { Percentage } \\
\text { change in ozone }\end{array}$ & $\begin{array}{l}\text { Percentage } \\
\text { change in } \mathrm{SO}_{2}\end{array}$ \\
\hline Jaipur & $-24.97 \%$ & $-29.69 \%$ & $-56.18 \%$ & $-25.86 \%$ & $-15.68 \%$ \\
Bhiwadi & $-58.22 \%$ & $-44.69 \%$ & $-64.41 \%$ & $+45.05 \%$ & $-69.91 \%$ \\
Alwar & $-47.33 \%$ & $-42.81 \%$ & $-30.22 \%$ & $+10.19 \%$ & $-42.79 \%$ \\
Jodhpur & $-30.00 \%$ & $-33.49 \%$ & $-56.69 \%$ & $+1.14 \%$ & $-38.96 \%$ \\
Kota & $-29.10 \%$ & $-29.341 \%$ & $-44.83 \%$ & $+22.93 \%$ & $-3.47 \%$ \\
Ajmer & $-47.62 \%$ & $-42.69 \%$ & $-32.72 \%$ & $+1.35 \%$ & $+2.09 \%$ \\
Udaipur & $-22.52 \%$ & $-23.73 \%$ & $-57.98 \%$ & $-0.52 \%$ & $+32.39 \%$ \\
\hline
\end{tabular}


Fig. 4 Photochemical reactions of formation and decomposition of ozone

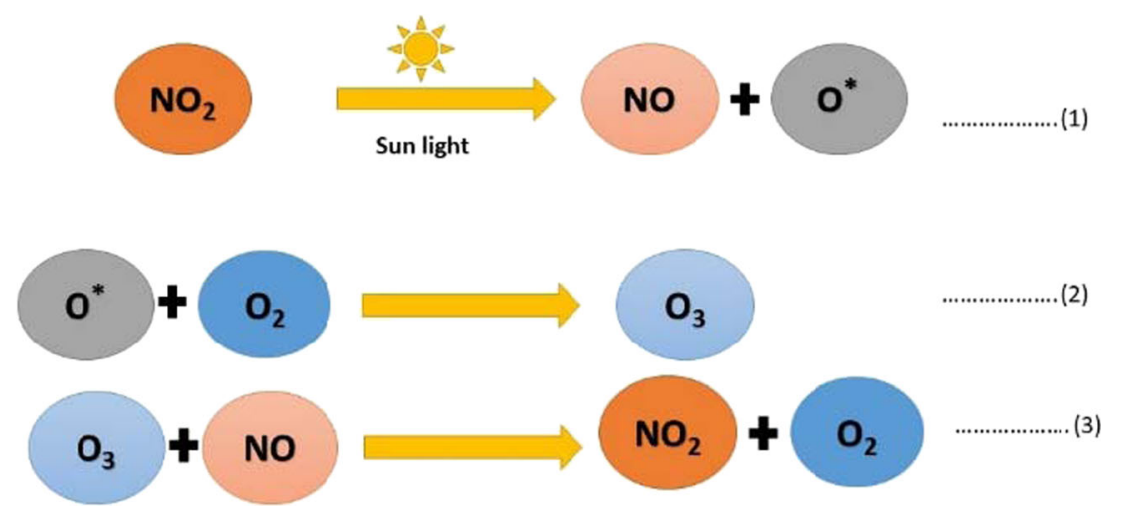

of industries and construction and demolition activities, depletion of road dust, refused burning, and reduction in electricity demand from thermal power plants.

The results are further analyzed based on the meteorological parameters. The meteorological parameters of the selected cities of Rajasthan are depicted in Table 4.

It is well-documented that the air quality is related to the meteorological parameters like wind speed, temperature, and relative humidity (Sharma et al. 2020). In the present study, we have summarized the wind speed and temperature before and after lockdown periods (Table 4). High temperature and high wind speed accelerate the dispersion of air pollutants in environment as compared with low temperature and calm wind speeds. As in Table 4, the average wind speed during the studied before lockdown period was $1.07 \mathrm{~m} / \mathrm{s}$ in Jaipur, $0.82 \mathrm{~m} / \mathrm{s}$ in Bhiwadi, $1.56 \mathrm{~m} / \mathrm{s}$ in Alwar, $0.86 \mathrm{~m} / \mathrm{s}$ in Jodhpur, $1.15 \mathrm{~m} / \mathrm{s}$ in Kota, $3.4 \mathrm{~m} / \mathrm{s}$ in Ajmer, and $2.34 \mathrm{~m} / \mathrm{s}$ in Udaipur. The wind speed observed an incline in all the cities except Ajmer, during lockdown periods (the three phases). Similarly, all the selected cities witnessed a rise in temperature during lockdown period as compared with before lockdown period. Thus, the meteorological conditions were more favorable for air pollutant dispersion during lockdown period. Therefore, beside lockdown, meteorological parameters also showed an impact on the improvement of air quality in most of the cities.

\section{Special area of study: Bhiwadi}

Bhiwadi is a city of Alwar district and is considered the industrial hub of Rajasthan. It has many small, medium, and large industries (Economic times 2012). Rajasthan State Industrial Development and Investment Corporation (RIICO) has improved its operations made Bhiwadi region of Alwar as an automotive hub by facilitating the establishment of different automobile manufacturing companies. The rapid industrialization and hence urbanization leads to evolution of different air pollutants affecting the air quality. In a report on continuous ambient air quality data of eight cities of Rajasthan (RSPCB (Rajasthan State Pollution Control Board) 2018), the concentration of $\mathrm{PM}_{10}$ was found as the highest $\left(201.24 \mu \mathrm{g} / \mathrm{m}^{3}\right)$ at Bhiwadi among the eight monitored cities. Also $\mathrm{PM}_{2.5}\left(68.10 \mu \mathrm{g} / \mathrm{m}^{3}\right.$ and $\mathrm{SO}_{2}\left(19.48 \mu \mathrm{g} / \mathrm{m}^{3}\right)$ was reported as the highest in Bhiwadi that must be due to the various industries located in and around the city.

Due to restricted activities amidst lockdown, the effect on the air quality of Bhiwadi is most significant (Fig. 2c). We have taken Bhiwadi as a representative city of Rajasthan to further study the impact on air quality. We have performed Wilcoxon signed rank test with data of previous year 2019 (10 March-17 May) and this year 2020 (10 March-17 May) to assess the effects of lockdown on air quality parameters in Bhiwadi.

The test shows that for Bhiwadi, all the air quality parameters, except ozone, are statistically significant $(p<0.05)$. All the parameters, except ozone, were found to be lower during March-May 2020 as compared with those during MarchMay 2019 (Table 5). For ozone $(p>0.05)$, it signifies that the ozone concentrations in study period 2019 and 2020 are not significantly different $(p$ value $=0.85)(69)$.

\section{Conclusion}

The study of air quality during lockdown situation, when the anthropogenic activities were minimized, is an excellent chance to ascertain the impact of human activities on the worsening of the environment (Saadat et al. 2020). During lockdown, most of the activities including industrial, transport, and tourism were put on hold and thus showed an improvement in the air quality of the selected cities of Rajasthan.

The air quality of different seven cities of state Rajasthan showed a trend of decrease in concentration of all the pollutants (except ozone) during lockdown period as compared with that of before lockdown period. The increase in concentration 


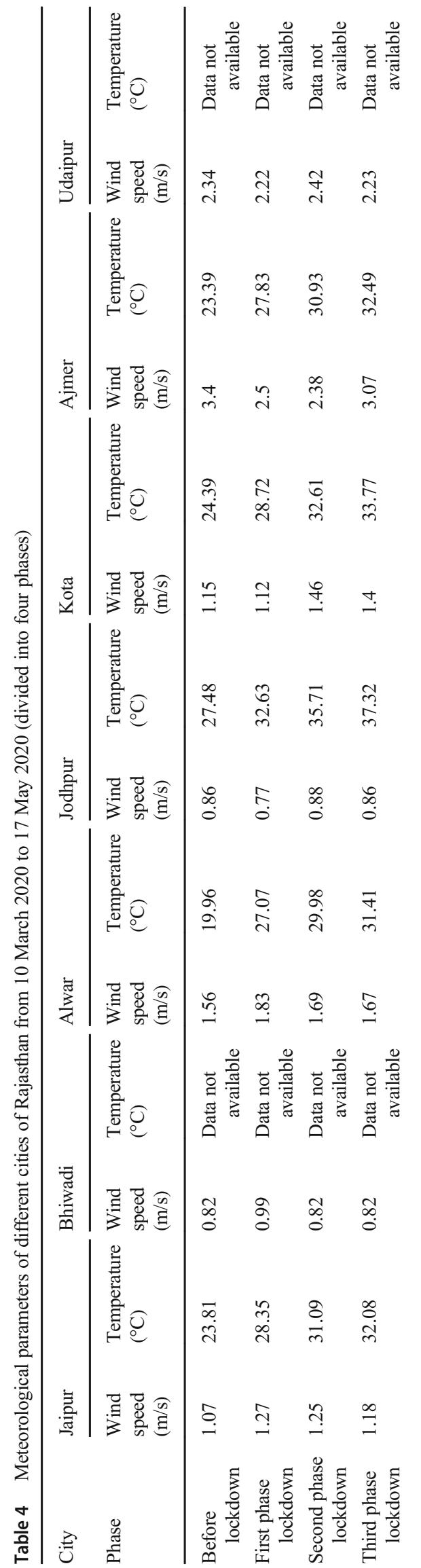

Table 5 Wilcoxon signed rank test on pollutants of Bhiwadi city

\begin{tabular}{llll}
\hline S. No. & Parameter & $\mathrm{Z}$ & $p$ value \\
\hline 1 & $\mathrm{PM}_{2.5}$ & -6.27 & 0 \\
2 & $\mathrm{PM10}$ & -6.93 & 0 \\
3 & Ozone & -0.19 & 0.85 \\
4 & $\mathrm{NO}_{2}$ & -0.69 & 0 \\
5 & $\mathrm{SO}_{2}$ & -6.008 & 0 \\
\hline
\end{tabular}

of ozone can be related to the decrease in NOx in the VOClimited conditions. Furthermore, one of the severely polluted cities, Bhiwadi, showed the maximum dip in air pollutants. The Wilcoxon signed rank test on the city concludes that significant difference is absent between mean values of study period for ozone. But for other parameters $\left(\mathrm{PM}_{2.5}, \mathrm{PM}_{10}\right.$, $\mathrm{NO}_{2}$, and $\mathrm{SO}_{2}$ ), there is a significant difference in their mean values.

We can safely say that the Covid- 19 pandemic is a lesson to learn from the benefits associated with the restriction of human activities during lockdown period not only in terms of safety but also as improvement in the air quality. As per the WHO report (WHO 2016), the deaths from air pollution share $7.6 \%$ of all the premature deaths, globally. The reduced pollution level can help nature to revive and may contribute in reduction of fatalities due to pollution.

The WHO reported that bringing down $\mathrm{PM}_{2.5}$ levels by $25 \mu \mathrm{g} \mathrm{m}^{-3}$ (from 35 to $10 \mu \mathrm{g} \mathrm{m}^{-3}$ ) would result in a reduction of $15 \%$ premature deaths (mortality) (WHO 2005a, b). Even though impact due to exposure to air pollution will not result in instantaneous mortality, and it is more of a chronic phenomenon. Therefore, immediate benefits would be more in terms of avoided morbidity and increased in healthy days. The lockdown was proven as an ideal strategy to tame pollution and its adverse effects on human health (Gautam 2020).

Acknowledgments The authors are grateful to their organization (University of Petroleum and Energy Studies) for the unconditional support and guidance during writing of the paper.

\section{References}

Aranha KD (1994). Environmental chemistry. New Age International Ltd. Publisher New Delhi 213-219

Bao R, Zhang A (2020) Does lockdown reduce air pollution? Evidence from 44 cities in northern China. Sci Total Environ 139052

Bherwani H, Nair M, Musugu K, Gautam S, Gupta A, Kapley A, Kumar R (2020) Valuation of air pollution externalities: comparative assessment of economic damage and emission reduction under COVID-19 lockdown. Air Qual Atmos Health 13:683-694

Chafe ZA, Brauer M, Klimont Z, Van Dingenen R, Mehta S, Rao S, Riahi K, Dentener F, Smith KR (2014) Household cooking with solid fuels contributes to ambient PM2.5 Air pollution and the burden 
of disease. Environ. Health Perspect 122:1314-1320. https://doi. org/10.1289/ehp. 1206340

Chauhan SS (2010) Mining, development and environment: a case study of Bijolia mining area in Rajasthan, India. J Hum Ecol 31(1):65-72

CNN Health 25th (2020) https:/edition.cnn.com/2020/02/25/health/ most-polluted-cities-india-pakistan-intl-hnk/index.html

CPCB (2020) https://app.cpcbccr.com/ccr/\#/caaqm-dashboard-all/ caaqm-landing

Dang R, Liao H (2019) Radiative forcing and health impact of aerosols and ozone in China as the consequence of clean air actions over 2012-2017. Geophys Res Lett 46(21):12511-12519

Dhamaniya R (2004) Goyal use of GIS in transportation planning of Jaipur city. GIS Dev 8(11):38-34

Dutheil F, Baker JS, Navel V (2020) COVID-19 as a factor influencing air pollution? Environ. Pollution (Barking, Essex: 1987) 263: 114466

Economic times (2012) http://articles.economictimes.indiatimes.com/ 2012-09-01/news/33535417_1_avalon-group-manesar-real-estate

Gautam S (2020) COVID-19: air pollution remains low as people stay at home. Air Qual Atmos Health 13:853-857

GOI (Government of India) 2020 https://www.mygov.in/covid-19/

Gorbalenya A E, Baker SC, Baric R, Groot RJD, Drosten C, Gulyaeva AA, Penzar D (2020) Severe acute respiratory syndrome-related coronavirus: the species and its viruses-a statement of the Coronavirus Study Group

Gurjar BR, Ravindra K, Nagpure AS (2016) Air pollution trends over Indian megacities and their local-to-global implications. Atmos Environ 142:475-495

Guttikunda S, Jawahar P, Gota S, KA N (2016) Urban Emissions.info, available at: http://www.urbanemissions.info (last access: 10 August 2017)

Guttikunda SK, Nishadh KA, Jawahar P (2019) Air pollution knowledge assessments (APnA) for 20 Indian cities. Urban Clim 27:124-141

IBEF : India Brand Equity Foundation (2020 https://www.ibef.org/ download/Rajasthan-March-2020.pdf

Jain S, Sharma T (2020) Social and travel lockdown impact considering coronavirus disease (COVID-19) on air quality in megacities of India: present benefits, future challenges and way forward. Aerosol Air Qual Res 20:1222-1236

Kala J, Sharma G, Kumar S, Pipralia S (2014) Study of ambient air quality status on urban roads using air quality index - a case of Jaipur City (Rajasthan, India). Int J Theoret Appl Sci 6(1):138-147

Kim S, Jeong D, Sanchez D, Wang M, Seco R, Blake D, Kim D (2018) The controlling factors of photochemical ozone production in Seoul, South Korea. Aerosol Air Qual Res 18(9):2253-2261

Kumar SS, Sharma K (2016) Ambient air quality status of Jaipur city, Rajasthan, India. Int Res J Environment Sci 5:43-48

Lee SC, Chiu MY, Ho KF, Zou SC, Wang X (2002) Volatileorganic compounds (VOCs) in urban atmosphere of HongKong. Chemosphere 48(3):375-382

Lelieveld J, Evans JS, Fnais M, Giannadaki D, Pozzer A (2015) The contribution of outdoor air pollution sources to premature mortality on a global scale. Nature 525:367-371. https://doi.org/10.1038/ nature 15371

Li K, Jacob DJ, Liao H, Shen L, Zhang Q, Bates KH (2019) Anthropogenic drivers of 2013-2017 trends in summer surface ozone in China. Proc Natl Acad Sci 116(2):422-427

Lu H, Stratton CW, Tang YW (2020) Outbreak of pneumonia of unknown etiology in Wuhan, China: the mystery and the miracle. J Med Virol 92(4):401-402

Maanju SK, Saha K (2013) Impact of mining industry on environmental fabric - a case study of Rajasthan state in India. Journal of Environmental Science Toxicology and Food Technology 6(2):813
Mandal I, Pal S (2020) COVID-19 pandemic persuaded lockdown effects on environment over stone quarrying and crushing areas. Science of The Total Environment:139281

Maps of India 2011, https://www.mapsofindia.com/maps/rajasthan/ quick-facts/area.html

Masum MH, Pal SK (2020) Statistical evaluation of selected air quality parameters influenced by COVID-19 lockdown. Global J. Environ. Sci. Manage. 6(SI):85-94

Pant M, Chandramauli MA (2018 A air quality assessment of Haldwani City of Uttarakhand

Report 2018 Rajasthan: steady strides into the future https://www.phdcci. in/wp-content/uploads/2018/11/Rajasthan-Steady-Strides-into-theFuture.pdf

RSPCB (Rajasthan State Pollution Control Board) (2018), http:// environment.rajasthan.gov.in/content/dam/environment/RPCB/ EnvironmentalReport/Brief\%20Report\%20July\%20to\% 20September\%202018.pdf

Saadat S, Rawtani D, Hussain CM (2020) Environmental perspective of COVID-19. Sci Total Environ 728:138870

Sahu SK, Beig G, Parkhi NS (2012) Emerging pattern of anthropogenic NOx emission over Indian subcontinent during 1990s and 2000s. Atmospheric Pollution Research 3(3):262-269

Saini R, Taneja A, Singh P (2017) Surface ozone scenario and air quality in the north-central part of India. Int J Environ Sci 59:72-79

Seinfeld JH, Pandis SN (1998) Atmospheric chemistry and physics. Wiley, New York

Sharma M, Dikshit O (2016) Comprehensive study on air pollution and green house gases (GHGs) in Delhi. A report submitted to Government of NCT Delhi and DPCC Delhi. 1-334

Sharma S, Chatani S, Mahtta R, Goel A, Kumar A (2016) Sensitivity analysis of ground level ozone in India using WRF-CMAQ models. Atmos Environ 131:29-40

Sharma S, Zhang M, Anshika GJ, Zhang H, Kota SH (2020) Effect of restricted emissions during COVID-19 on air quality in India. Sci Total Environ 728:138878

Sheikh M, Najar IA (2018) Preliminary study on air quality of Srinagar, (J\&K), India. Journal of Environmental Science Studies 1(1):45

Shrestha AM, Shrestha U B, Sharma R, Bhattarai S, Tran HNT, Rupakheti M (2020) Lockdown caused by COVID-19 pandemic reduces air pollution in cities worldwide

Sicard P, De Marco A, Agathokleous E, Feng Z, Xu X, Paoletti E, Calatayud V (2020) Amplified ozone pollution in cities during the COVID-19 lockdown. Science of The Total Environment:139542

Singh J (2018) Paddy and wheat stubble blazing in Haryana and Punjab states of India: a menace for environmental health. Environ Qual Manag 28(2):47-53

Srivastava A, Joseph AE, More A, Patil S (2005) Emissions of VOCs at urban petrol retail distribution centres in India (Delhiand Mumbai). Environ Monit Assess 109(1-3):227-242

Tandon A, Yadav S, Attri AK (2008) City-wide sweeping a source for respirable particulate matter in the atmosphere. Atmos Environ 42(5):1064-1069

TOI (Times of India) (2018) https://weather.com/en-IN/india/pollution/ news/2018-12-10-rajasthan-highest-death-rate-air-pollution-india

WAQR, World air quality report (2018) https://www.iqair.com/worldmost-polluted-countries

WAQR, World air quality report (2019) https://www.iqair.com/worldmost-polluted-countries

WHO (2005a) WHO Air quality guidelines for particulate matter, ozone, nitrogen dioxide and sulfur dioxide. https://apps.who.int/iris/ bitstream/handle/10665/69477/WHO_SDE_PHE_OEH_06.02_ eng.pdf?sequence $=1$

WHO (2005b) Air quality guidelines global update published by World Health Organisation

WHO (2016) Global Health Observatory (GHO) data, https://www.who. int/gho/phe/outdoor_air_pollution/en/ 
WHO (2020) Coronavirus disease (COVID-19) pandemic https://www. who.int/emergencies/diseases/novel-coronavirus-2019

Xu K, Cui K, Young LH, Hsieh YK, Wang YF, Zhang J, Wan S (2020) Impact of the COVID-19 event on air quality in Central China. Aerosol Air Qual Res 20(5):915-929
Yadav R, Sahu LK, Jaaffrey SNA, Beig G (2014) Temporal variation of Particulate atter (PM) and potential sources at an urban site of Udaipur in Western India. Aerosol Air Qual Res 14(6):1613-1629

Publisher's note Springer Nature remains neutral with regard to jurisdictional claims in published maps and institutional affiliations. 